\title{
Psychrotrophic Pseudomonas mandelii CBS-1 produces high levels of poly- $\beta$-hydroxybutyrate
}

\author{
Rongpeng $\mathrm{Li}^{1}$, Yuji Jiang ${ }^{2}$, Xinfeng Wang ${ }^{3}$, Jingjing Yang ${ }^{1}$, Yuan Gao ${ }^{1}$, Xiaoli Zi ${ }^{1}$, Xia Zhang ${ }^{1}$, Haofeng Gao \\ and $\mathrm{Nan} \mathrm{Hu}{ }^{1 *}$
}

\begin{abstract}
A novel facultative psychrotroph (strain CBS-1), which accumulates poly- $\beta$-hydroxybutyrate (PHB), was isolated from soil samples taken from Changbai Mountain, China. Phylogenetic analysis based on 165 rRNA sequence data and Biolog analysis identified strain CBS-1 as Pseudomonas mandelii. Transmission electron micrographs revealed abundant electron-transparent intracellular granules. ${ }^{1} \mathrm{H}$-nuclear magnetic resonance analysis revealed that the granules were composed of PHB. P. mandelii CBS-1 grew optimally at $20^{\circ} \mathrm{C}$. When cultured aerobically for $48 \mathrm{~h}$ with sucrose as the sole carbon source, strain CBS-1 yielded a maximum cell density of $29.3 \mathrm{~g} / \mathrm{L}$ cell dry weight and synthesized $22.3 \mathrm{~g} / \mathrm{L}$ of PHB. The ability of strain CBS-1 to grow at a low temperature and rapidly synthesize high levels of PHB may reduce the costs of industrial PHB production.
\end{abstract}

Keywords: PHB; Pseudomonas mandelii CBS-1; Facultative psychrotrophs; ${ }^{1} \mathrm{H}$ - nuclear magnetic resonance; Fermentation

\section{Background}

Polyhydroxyalkanoates (PHAs) are biodegradable polyesters composed of (R)-3HA monomers, which are ubiquitously synthesized by microorganisms. Many bacteria store carbon as PHAs to protect themselves from nutrient limitation, including lack of nitrogen, phosphorus, and magnesium (Dowes and Senior, 1973). PHAs are synthesized by most genera of Bacteria and (Archaea Steinuchel and Byrom, 1991). The best-characterized microorganisms that produce PHAs are Alcaligenes sp. (Linko et al., 1993), Azotobacter sp. (Page, 1992), Bacillus sp. (Huang and Reusch, 1996), Rhodopseudomonas sp. (Yue et al., 2007), and Pseudomonas sp. (Kimura et al., 1992).

Poly- $\beta$-hydroxybutyrate (PHB), the least complex PHA biopolyester, offers distinct advantages for polyester production because of its biodegradability, lighter mass, thermoplasticity, and resistance to abrasion (Steinbuchel and Valeniin, 1995). PHB shows great potential for manufacturing products such as degradable plastics, medical implant materials, and fine chemicals (Holemes, 1985). Unfortunately, available bacterial strains synthesize low

\footnotetext{
* Correspondence: hunannjut@126.com

${ }^{1}$ Colloge of Biotechnology and Pharmaceutical Engineering, Nanjing University of Technology, Nanjing 211800, People's Republic of China Full list of author information is available at the end of the article
}

levels of PHB even after prolonged fermentation. Therefore, PHB biosynthesis is more expensive than standard chemical synthesis and limits its use (Choi and Lee, 1999).

Therefore, the goal of our research was to isolate bacteria capable of producing high levels of PHB at low temperatures. We report here the isolation of a facultative psychrotrophic strain (CBS-1) from the soil of Changbai Mountain, China, and its identification as Pseudomonas mandelii. It is the first report of PHB accumulation in $P$. mandelii. Strain CBS-1 grew aerobically to a dry-cell weight of $29.3 \mathrm{~g} / \mathrm{L}$ and synthesized $22.3 \mathrm{~g} / \mathrm{L}$ of PHB in $48 \mathrm{~h}$, which is higher compared with other reported strains (Kimura et al., 1992; Huang and Reusch, 1996; Yue et al., 2007).

\section{Material and methods}

Strains, growth media, and culture condition

A soil sample from Changbai Mountain (altitude 2183 m, N 42 08'19.7", E 128 10'8.3"), Jilin Province, China, was suspended in sterile $\mathrm{H}_{2} \mathrm{O}$, vortexed thoroughly, and cultured in an enriched medium containing $5 \mathrm{~g} / \mathrm{L}$ yeast extract, $10 \mathrm{~g} / \mathrm{L}$ tryptone, and $2.5 \mathrm{~g} / \mathrm{L} \mathrm{NaCl}$ at $20^{\circ} \mathrm{C}$ for 2 days. A $50-\mu \mathrm{L}$ aliquot was spread on PHB detection agar (20 g/L glucose, $2 \mathrm{~g} / \mathrm{L}\left(\mathrm{NH}_{4}\right)_{2} \mathrm{SO}_{4}, 13.3 \mathrm{~g} / \mathrm{L} \mathrm{KH}_{2} \mathrm{PO}_{4}, 1.2$ $\mathrm{g} / \mathrm{L} \mathrm{MgSO}_{4} 7 \mathrm{H}_{2} \mathrm{O}, 1.7 \mathrm{~g} / \mathrm{L}$ citric acid, $1.7 \mathrm{~g} / \mathrm{L}$ trace elements solution, $15 \mathrm{~g} / \mathrm{L}$ agar, and $0.5 \mu \mathrm{g} / \mathrm{mL}$ Nile blue A 
(Spiekermann et al., 1999). After overnight incubation at $20^{\circ} \mathrm{C}$, plates were observed under ultraviolet (UV) light. Fluorescent colonies were purified by streaking on the same agar plates, and the isolates were further characterized by staining with Sudan Black B (Lee and Choi, 2004).

\section{Morphological characteristics}

Cell morphology was examined using transmission electron microscopy as follows: a 2-mL aliquot of cells in late exponential phase (optical density $\mathrm{OD}_{600} 55-80$ ) was fixed with $4 \%$ glutaraldehyde and $1 \%$ osmium tetroxide and dehydrated by sequential treatment with 30\%, 50\%, 70\%, $80 \%, 90 \%$, and $100 \%$ acetone. The dehydrated cells were immersed in epoxy resin and then transferred into sample boats. The resin was polymerized for $24 \mathrm{~h}$ at 30,45 , and $60^{\circ} \mathrm{C}$. Ultra-thin sections were prepared using an ultramicrotome, stained sequentially with uranyl acetate and lead citrate for $22 \mathrm{~min}$ and $5 \mathrm{~min}$, respectively, and observed using an H-7650 transmission electron microscope (Hitachi, Tokyo, Japan).

\section{Biolog Gram-negative (GN) assay}

Gram staining was performed as described by Magee et al. (1975). A pure culture was grown on a BUG agar plate (Biolog Catalog \#70101). Biolog ${ }^{\mathrm{TM}}$ GN 96-well microtiter plates contain 95 different carbon sources, a negative control, and a tetrazolium dye (Biolog Inc., Hayward, CA, USA). Cells were swabbed from the surface of the plate and suspended to a specific density in GN Inoculating Fluid (Biolog Catalog \#72101). The well of the Biolog GN2 MicroPlate (Biolog Catalog \#1011) was inoculated individually with $150 \mu \mathrm{L}$ of diluted suspensions and then incubated at $30^{\circ} \mathrm{C}$ for $24 \mathrm{~h}$ (Garland and Mills, 1991). The MicroPlate was inspected either visually or analyzed using the Biolog MicroStation ${ }^{\mathrm{Tm}}$ and the results compared with the GN III Database according to the manufacturer's instructions (Biolog Catalog \#22730D).

\section{Polymerase chain reaction (PCR) amplification of the $16 \mathrm{~S}$ rRNA gene}

The 16S rRNA gene was amplified using PCR with the universal bacterial primers $27 \mathrm{~F}$ ( $5^{\prime}$-agagttgatcctggctcag- $\left.3^{\prime}\right)$ and 1492R (5'-ggytaccttgttacgactt-3') (Lane, 1991), and the product was sequenced by Takara Corp. (Dalian, China). The sequence was compared with $16 \mathrm{~S}$ rRNA gene sequences in the GenBank database (http://www.ncbi.nlm. nih.gov) using the BLAST algorithm (Altschul et al., 1990). A neighbor-joining tree was constructed using the MEGA 4.0 program (Kumar et al., 2004).

\section{Poly- $\beta$-hydroxybutyrate extraction}

Cells were harvested and treated with $10 \%$ sodium dodecyl sulfate at $100^{\circ} \mathrm{C}$ for $15 \mathrm{~min}$. After centrifugation at $10,000 \mathrm{rpm}$ for $20 \mathrm{~min}$, the pellets were washed twice with $\mathrm{H}_{2} \mathrm{O}$, dried at $40^{\circ} \mathrm{C}$, and extracted with chloroform for $1 \mathrm{~h}$ at $60^{\circ} \mathrm{C}$. Insoluble material was removed by filtration, and the soluble PHB was separated from the chloroform phase by evaporation, washed twice with methanol, filtered, dried at $60-70^{\circ} \mathrm{C}$, and weighed using an electronic balance (Sartorius, BSA224S).

\section{Nuclear magnetic resonance (NMR) spectroscopy}

The NMR spectra of 1-mL samples were recorded using a BRUAK AV-400 spectrometer with a $5-\mathrm{mm}{ }^{1} \mathrm{H}$-probe, and deuterated chloroform $\left(\mathrm{CDCl}_{3}\right)$ was used as a solvent at a final concentration of $10 \mathrm{~g} / \mathrm{L}$. The ${ }^{1} \mathrm{H}-\mathrm{NMR}$ spectrum for PHB was recorded at $400 \mathrm{MHz}$. A PHB standard was purchased from Sigma-Aldrich (St. Louis, MO, USA, \#MSDS 363502).

\section{Effect of culture conditions on cell growth}

The effects on cell growth of carbon and nitrogen sources, $\mathrm{C} / \mathrm{N}$ ratio, temperature, initial $\mathrm{pH}$, and $\mathrm{NaCl}$ concentration were investigated using single-factor tests (Tang and Luo, 2008). Specifically, yeast extract, glucose, sucrose, fructose, glycerol, and ethanol were used as carbon source. Nitrogen sources included tryptone, peptone, beef extract, monosodium glutamate, urea, and $\mathrm{NH}_{4} \mathrm{Cl}$. All media contained $1.0 \mathrm{~g} / \mathrm{L} \mathrm{KH_{2 }} \mathrm{PO}_{4}, 2.5 \mathrm{~g} / \mathrm{L} \mathrm{Na}_{2} \mathrm{HPO}_{4}, \mathrm{pH} 7.0$, and cells were cultured at $20^{\circ} \mathrm{C}, 200 \mathrm{rpm}$. To test the effect of the $\mathrm{C} / \mathrm{N}$ ratio, sucrose and monosodium glutamate served as the sole carbon and nitrogen sources and were added at the $\mathrm{C} / \mathrm{N}$ ratios as follows: $1,5,10,15,20,25$, and 30 . Other conditions were the same as those described above. The optimum $\mathrm{C} / \mathrm{N}$ ratio was used to test the conditions described next. $\mathrm{NaCl}$ concentrations were varied from 0 $50 \mathrm{~g} / \mathrm{L}$ (5-g/L intervals), and at initial $\mathrm{pH}$ values from 5.0 to 9.0 (0.5 pH unit intervals). Cultures were incubated from $5^{\circ} \mathrm{C}$ to $40^{\circ} \mathrm{C}\left(5^{\circ} \mathrm{C}\right.$ intervals). After 3 days, cells were collected by centrifugation, and the pellets were dried at $70^{\circ} \mathrm{C}$ to a constant weight.

\section{PHB production by aerated cultures}

Cells was cultured at $20^{\circ} \mathrm{C}$ in medium containing $1.0 \mathrm{~g} / \mathrm{L}$ $\mathrm{KH}_{2} \mathrm{PO}_{4}, 2.5 \mathrm{~g} / \mathrm{L} \mathrm{Na}_{2} \mathrm{HPO}_{4}$, with optimal 1\% (w/v) sucrose as the carbon source and monosodium glutamate as the nitrogen source. The $\mathrm{pH}$ was adjusted to 7.0 with 0.5 M NaOH. A 10-mL inoculum from a CBS-1 starter culture $\left(\mathrm{OD}_{600} 0.5\right)$ was added to a $150-\mathrm{mL}$ minimal medium. The $250-\mathrm{mL}$ flasks were incubated at $20^{\circ} \mathrm{C}$ for at least 3 days and shaken at $200 \mathrm{rpm}$. Samples were collected at 8 -h intervals from $0-72 \mathrm{~h}$, centrifuged, and dried at $70^{\circ} \mathrm{C}$ to a constant weight.

\section{Statistical analysis}

All results are shown as the average and standard deviation of at least three independent experiments. Student's $t$-test, analysis of variance (ANOVA), and Duncan's 
multiple range test were used to determine the statistical significance of differences in the nitrite-to-nitrogen conversion rate. Statistical significance was defined as $P<$ 0.05. All analyses were performed using SPSS for Windows version 11.0.

\section{Results}

Isolation and characterization of strain CBS-1

Oxazine dye Nile blue A was used to develop a simple and highly sensitive staining method to directly detect poly-3-hydroxybutyric acid and other PHAs in growing bacterial colonies (Spiekermann et al., 1999). A 50- $\mu$ l soil sample from Changbai Mountain, Jilin Province, China, was spread on PHB-detection agar containing Nile blue A stain (Lee and Choi, 2004). After incubation and observation under UV light, 59 fluorescent colonies were purified, and 27 were stained by Sudan Black B. A clone isolated from the largest and most intensely stained colony was named strain CBS-1. After incubation for 2 days on LB plates, CBS-1 formed white, circular colonies of semitransparent slabs that were wet with smooth surfaces. The bacilliform cells were GN, $3-4 \mathrm{~mm}$ in diameter $\times 5-7 \mathrm{~mm}$ long, and did not form spores. The cells occurred singly or in clusters and contained large granules of PHB (Figure 1).

A stretch of 1335 nucleotides of the 16S rRNA gene was PCR amplified and sequenced. The sequence was submitted to GenBank under the accession number KC778401. BLAST analysis indicated that strain CBS-1 is most closely related ( $99 \%$ identity) to P. mandelii. Phylogenetic analysis also grouped CBS-1 together with P. mandelii with $96 \%$ bootstrap support (Figure 2).

The GN III MicroPlate Database (Biolog Catalog \#22730D) identifies 564 common species in accordance with classical identification methods and current taxonomic nomenclature. Unfortunately, P. mandelii was not present in the database. The GN MicroPlate performance characteristics indicated that strain CBS-1 was similar to $P$. fluorescens biovar C. The similarity index was 0.81 at $24 \mathrm{~h}$ (Table 1). P. mandelii is classified in the

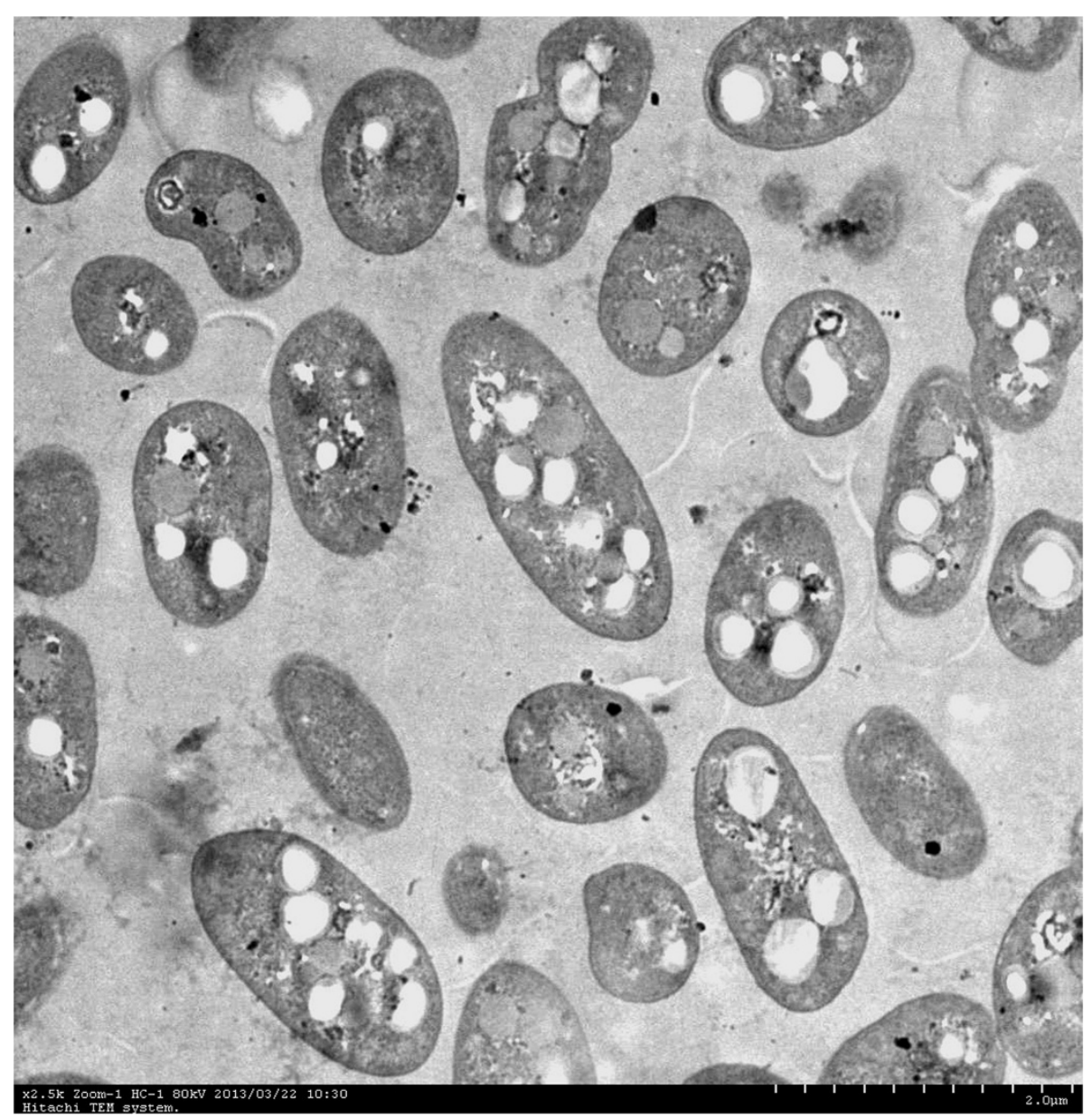

Figure 1 Transmission electron micrograph of a thin section showing dividing P. mandelii CBS-1-containing granules of PHB. Magnification 2,500x. 


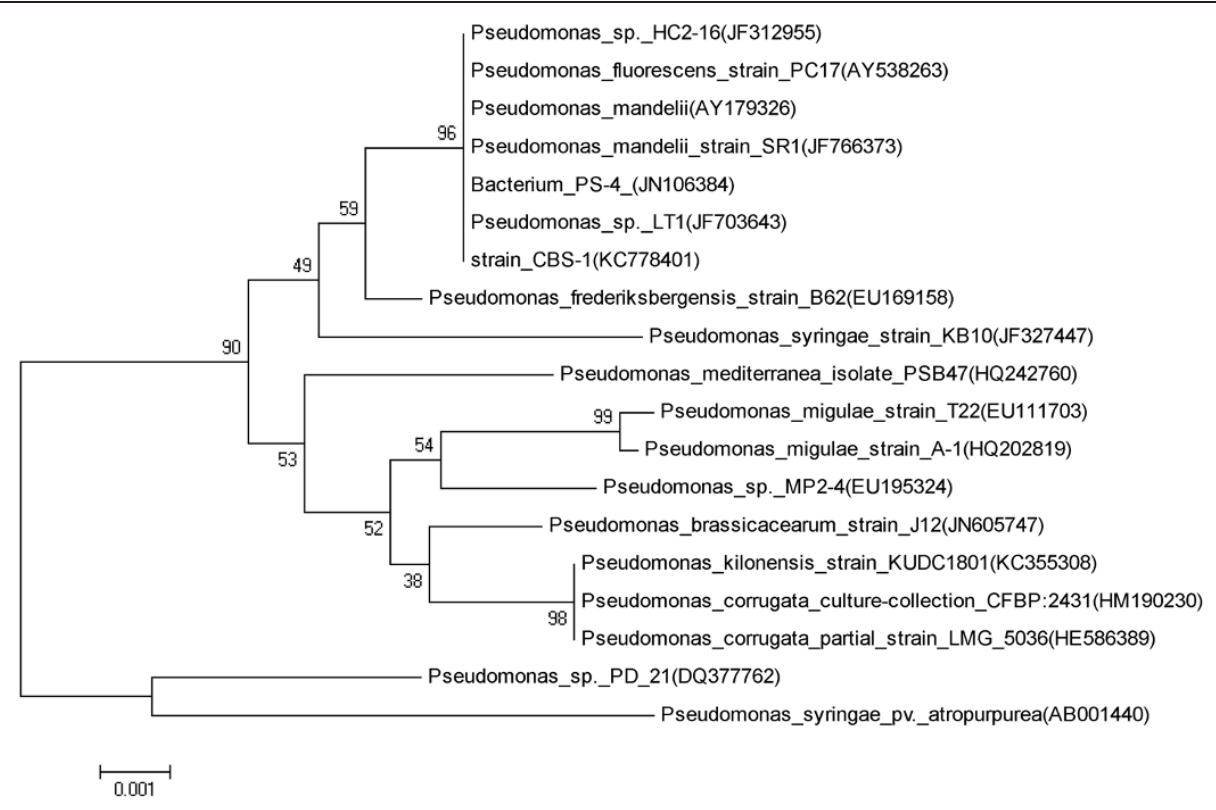

Figure 2 Phylogenetic tree of $\boldsymbol{P}$. mandelii CBS-1 and other related bacterial genera. Bootstrap values (\%) from 1,000 replicates are as shown. The scale bar represents 0.01 nucleotide substitution per position. Numbers in brackets are GenBank accession numbers for the $16 \mathrm{~S}$ rRNA sequences.

P. fluorescens species (Anzai et al., 2000). Therefore, the Biolog GN assay result did not contradict the 16S rRNA gene sequence, and we concluded that CBS-1 is a $P$. mandelii strain.

\section{Physiological characteristics of CBS-1}

Sucrose and monosodium glutamate were the optimum carbon and nitrogen sources for culturing CBS-1 (Table 2) at a $\mathrm{C} / \mathrm{N}$ ratio of 5 (Figure 3B). Strain $\mathrm{CBS}-1$ grew to

Table 1 Biochemical characteristics of strain CBS-1 and related Pseudomonas species

\begin{tabular}{lccc}
\hline Growth on: & $\begin{array}{c}\text { Strain } \\
\text { CBS-1 }\end{array}$ & $\begin{array}{c}\text { P. fluorescens } \\
\text { biovar C }\end{array}$ & $\begin{array}{c}\text { P. fluorescens } \\
\text { A2a5 }^{\mathbf{b}}\end{array}$ \\
\hline L-Arabinose & + & + & + \\
a-L-Rhamnose & - & - & - \\
Sucrose & + & + & + \\
Sebacic acid & - & - & - \\
Succinic acid & - & - & + \\
L-Asparagine & + & + & + \\
L-Aspartic acid & + & + & + \\
L-Histidine & + & + & + \\
L-Leucine & + & + & + \\
L-proline & + & + & + \\
L-Theronine & + & + & + \\
\hline
\end{tabular}

+ Positive; -, negative.

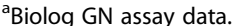

${ }^{\mathrm{b}}$ Data from Jiang et al., (2008). significant numbers between 10 and $35^{\circ} \mathrm{C}$, and the optimum growth temperature was $20^{\circ} \mathrm{C}$ (Figure 3A). Strain CBS-1 grew between pH 6.0 and 9.0 and optimally between pH 7.0 and 7.5 (Figure 3C). Significant growth was observed in media containing $0-3 \% \mathrm{NaCl}$ (Figure 3D).

\section{PHB synthesis by CBS-1}

After extracting cells with SDS and isolating PHB as a dried residue as described in Materials and methods, we conducted ${ }^{1} \mathrm{H}-\mathrm{NMR}$ analysis (Figure 4). PHB peaks were detected at $\delta=5.2,2.5$, and $1.2 \mathrm{ppm}$, which correspond to a $-\mathrm{CH}$ doublet, a $-\mathrm{CH}_{2}$ multiplet, and a $-\mathrm{CH}_{3}$ doublet, respectively (Verlinden et al., 2011; De Rooy et al., 2007). The large peak at $\delta=7.3 \mathrm{ppm}$ represents the solvent $\left(\mathrm{CD}_{3} \mathrm{Cl}\right)$, and the peaks at $\delta=0.0 \mathrm{ppm}$ and $\delta=$ $0.8 \mathrm{ppm}$ represent the internal standard $\left(\mathrm{CH}_{3}\right)_{4} \mathrm{Si}$. A

Table 2 Effect of different carbon and nitrogen sources on PHB synthesis by strain CBS-1

\begin{tabular}{lccc}
\hline $\begin{array}{l}\text { Carbon } \\
\text { sources }\end{array}$ & $\begin{array}{c}\text { Cell dry } \\
\text { weight } \mathbf{( g / L )}\end{array}$ & $\begin{array}{c}\text { Nitrogen } \\
\text { source }\end{array}$ & $\begin{array}{c}\text { Cell dry } \\
\text { weight } \mathbf{( g / L})\end{array}$ \\
\hline Yeast extract & $30.2 \pm 3.1$ & Tryptone & $19.0 \pm 0.9$ \\
Glucose & $9.9 \pm 1.4$ & Peptone & $17.4 \pm 1.8$ \\
Sucrose & $29.1 \pm 3.0$ & Beef extract & $18.4 \pm 1.3$ \\
Fructose & $7.8 \pm 1.1$ & Monosodium glutamate & $23.5 \pm 1.0$ \\
Glycerol & $16.3 \pm 2.9$ & Urea & $11.5 \pm 0.8$ \\
Ethanol & $2.9 \pm 0.2$ & $\mathrm{NH}_{4} \mathrm{Cl}$ & $13.6 \pm 1.5$ \\
\hline
\end{tabular}



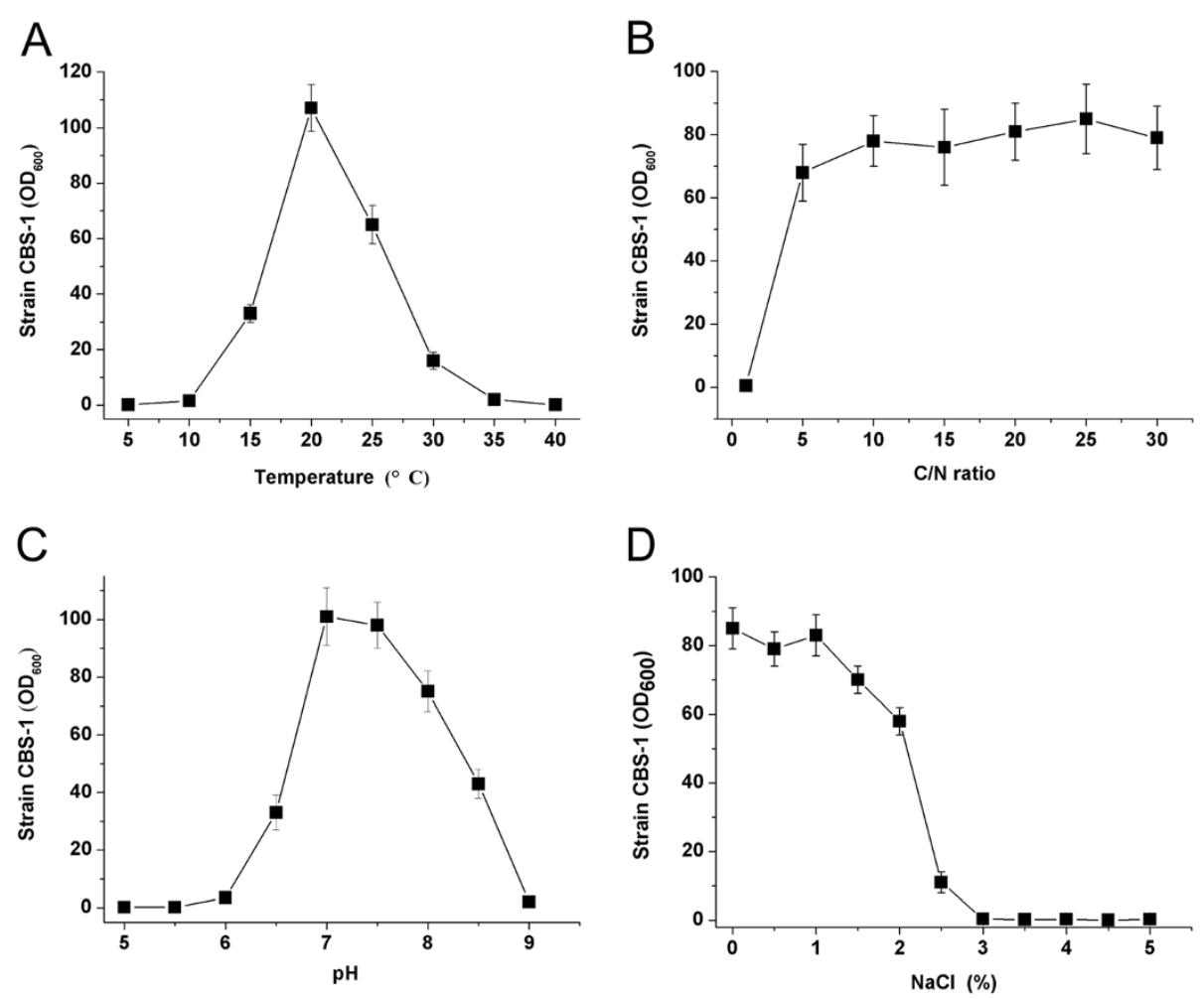

Figure 3 Effect of culture conditions on $\mathbf{P}$. mandelii CBS-1 growth. Effects of temperature (A), C/N ratio (B), pH (C), and NaCl concentration (D) were investigated.

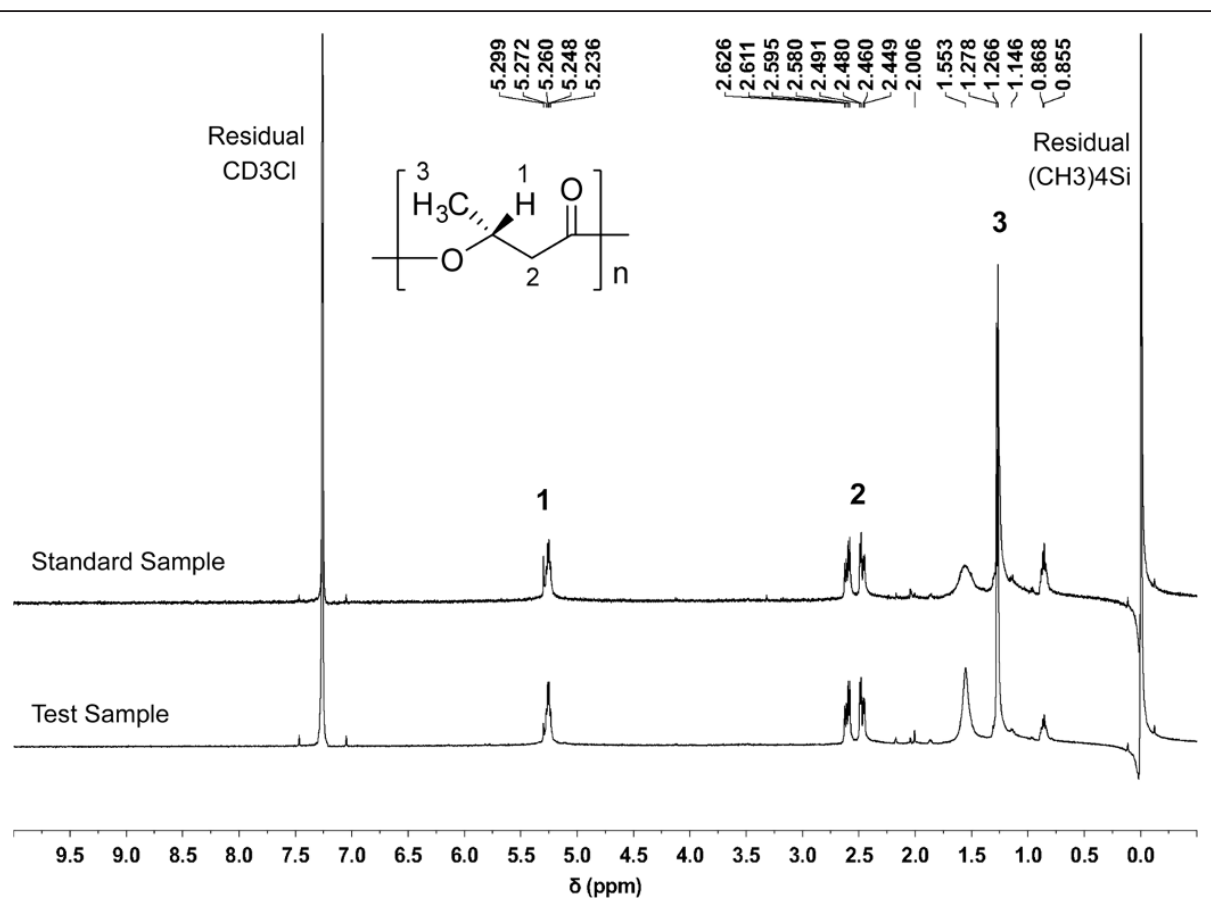

Figure $4{ }^{1} \mathrm{H}-\mathrm{NMR}$ spectra of a PHB standard and the PHB produced by $P$. mandelii CBS-1. 
small peak at $\delta=1.6 \mathrm{ppm}$ was attributed to minor contamination of the solvent with $\mathrm{H}_{2} \mathrm{O}$. These results were identical to those for the PHB standard. Therefore, we concluded that the only PHA synthesized by strain CBS1 grown in the presence of sucrose as the carbon source was PHB.

\section{PHB production in aerated CBS-1 cultures}

Strain CBS-1 was cultured in 150-mL sucrose-containing medium, $\mathrm{pH} 7.0$, at $20^{\circ} \mathrm{C}$ in a $250-\mathrm{mL}$ flask, which was shaken as described in Materials and methods. Cells were harvested upon reaching the stationary phase $(48 \mathrm{~h})$. The CDW was $29.3 \mathrm{~g} / \mathrm{L}$, and the PHB concentration reached $22.3 \mathrm{~g} / \mathrm{L}$ (Figure 5). The concentrations of PHB were $9 \mathrm{~g} / \mathrm{L}$ and $13 \mathrm{~g} / \mathrm{L}$ when the cells were grown at $15^{\circ} \mathrm{C}$ and $25^{\circ} \mathrm{C}$, respectively, under the same conditions. These data indicate that the yields of PHB depend critically on growth temperature.

\section{Discussion}

Because of the efficient and diverse biosynthetic capabilities of psychrotrophs at relatively low temperatures, these organisms provide an important resource for biotechnology (Moyer and Morita, 2007). Soil samples acquired at circumpolar latitudes are rich in psychrotrophs. For example, Jiang et al. (2008) first isolated the P. fluorescens strain A2a5 from Alaskan soil, and the P. extremaustralis sp. nov. strain 14- $3^{T}$ was isolated from an ephemeral pond in Antarctica (Lopez et al., 2009). These two psychrotrophs accumulate large amounts of PHB at a low temperature, strain $\mathrm{A} 2 \mathrm{a} 5$ grew at $25^{\circ} \mathrm{C}$, while strain $14-3^{\mathrm{T}}$ could grow at a temperature range from 4 to $37^{\circ} \mathrm{C}$. The nucleotide sequence of the genome of strain $14-3^{\mathrm{T}}$ has been determined (Tribelli et al., 2012).

Regions of high mountains perennially covered with snow are another abundant source of psychrotrophs. The mean temperature above $2000 \mathrm{~m}$ on Changbai Mountain is $3.3^{\circ} \mathrm{C}$ (Liu 1997). We report here the isolation of a $P$. mandelii strain designated CBS-1, a facultative psychrotroph, from soil located at an altitude of $2183 \mathrm{~m}$. Species identification was based on sequence analysis of $16 \mathrm{~S}$ rRNA and the results of the Biolog GN assay. Strain CBS-1 grew to high density (29.3 g/L of $\mathrm{CDW}$ at the stationary phase) and robustly produced PHB $(76.1 \% \mathrm{CDW})$ at $20^{\circ} \mathrm{C}$. The yields of PHB produced at 15,20 , and $25^{\circ} \mathrm{C}$ were significantly different. The yield of $\mathrm{PHB}$ produced at $20^{\circ} \mathrm{C}$ was significantly higher than at $15^{\circ} \mathrm{C}(P<0.001)$ and $25^{\circ} \mathrm{C}(P<0.05)$.

Compared with a few other Pseudomonas strains that produce $\mathrm{PHB}$ at a low temperature, strain CBS-1 is more promising for industrial use. For example, strain CBS-1 uses sucrose as its best carbon source; therefore, PHB can be produced more economically than by strain $14-3^{\mathrm{T}}$, which requires the more costly carbon source octanoate (Lopez et al., 2009). Moreover, strain CBS-1 grew to a higher maximum cell density than strain $14-3^{\mathrm{T}}$ (Lopez et al., 2009). Jiang et al. (2008) reported that cultivation for 4 days was required to produce the maximum cell density of strain A2a5 and PHB concentration, in contrast to $48 \mathrm{~h}$ for strain CBS-1. Therefore, strain CBS-1 may produce higher yields of PHB at a lower cost. Therefore, strain CBS-1 may produce higher yields of $\mathrm{PHB}$ at a lower cost and more efficiently than strain 14- $3^{\mathrm{T}}$ and $\mathrm{A} 2 \mathrm{a} 5$.

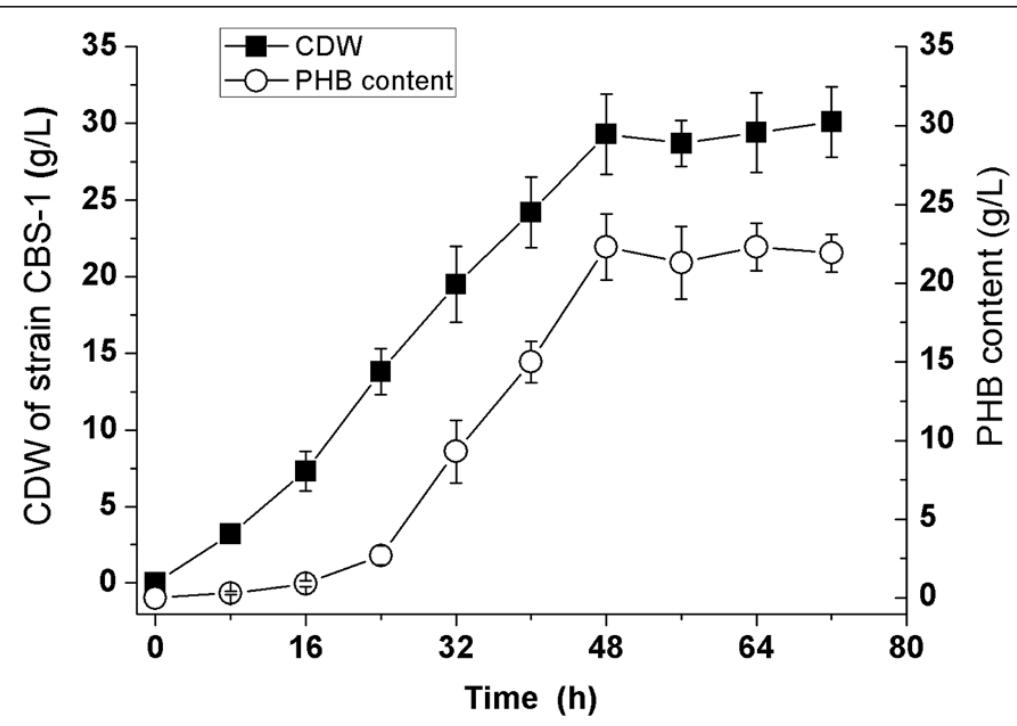

Figure 5 Aerobic growth of $P$. mandelii CBS-1 and PHB production at $20^{\circ} \mathrm{C}$ in a medium containing sucrose as carbon source. Each point represents the average of three cultures. 


\section{Competing interests}

The authors declare that they have no competing interests.

\section{Authors' contributions}

LRP, JYJ and HN carried out the strains isolation, characteristics, PHB extraction and identification, and drafted the manuscript. WXF carried out the Biolog Gram-negative assay. YJJ carried out the 16S rRNA gene amplication. GY and ZXL carried out researches on effect of culture conditions on cell growth. ZX and GHF participated in the cell cultivations and 165 rRNA sequence alignment. All authors read and approved the final manuscript.

\section{Authors' information}

Rongpeng Li and Yuji Jiang co-first author.

\section{Acknowledgments}

This research was supported by for National Science Foundation of China (No. 51008012) and Open Science Foundation of Jiangsu Key Laboratory for Biomass-based Energy and Enzyme Technology (No. JSBEET1314).

\section{Author details}

${ }^{1}$ Colloge of Biotechnology and Pharmaceutical Engineering, Nanjing University of Technology, Nanjing 211800, People's Republic of China. ${ }^{2}$ Institute of Soil Science, Chinese Academy of Sciences, Nanjing 210008, People's Republic of China. ${ }^{3}$ Jiangsu Key Laboratory for Biomass-based Energy and Enzyme Technology, Huaian 223300, People's Republic of China.

Received: 12 April 2013 Accepted: 19 July 2013

Published: 23 July 2013

\section{References}

Altschul SF, Gish W, Miller W, Myers EW, Lipman DJ (1990) Basic local alignment search tool. J Mol Biol 215:403-140

Anzai Y, Kim H, Park JY, Wakabayashi H, Oyaizu H (2000) Phylogenetic affiliation of the Pseudomonads based on $16 \mathrm{~S}$ rRNA sequence. Int J Sys Evol Microbiol 50:1563-1589

Choi J, Lee SY (1999) Factors affecting the economics of polyhydroxyalkanoate production by bacterial fermentation. Appl Microbiol Biotechnol 51:13-21

De Rooy SL, Wahyuni ET, Wiratni SS, Ismail J (2007) Purification and characterization of poly-hydroxybutyrate (PHB) in Cupriavidus necator. Indo J Chem 7:243-248

Dowes EA, Senior PJ (1973) The role and regulation of energy reserve polymers in microorganisms. Adv Miacrobiol Physiol 10:135-266

Garland JL, Mills L (1991) Classification and characterization of heterotrophic microbial communities on the basis of patterns of community-level solecarbon-source utilization. App Environ Microbiol 57:2351-2359

Holemes PA (1985) Applications of PHB: a microbially produced biodegradable thermoplastic. Phys Technol 16:32-36

Huang R, Reusch RN (1996) Poly(3- hydroxybutyrate) is associated with specific proteins in the cytoplasm and membranes of Escherichia coli. J Biol Chem 371:22196-22202

Jiang YJ, Song X, Gong L, Li P, Dai CC, Shao WL (2008) High poly ( $\beta$ hydroxybutyrate) production by Pseudomonas fluorescens A2a5 from in expensive substrates. Enzyme Microb Technol 42:167-172

Kimura H, Yoshida Y, Doi Y (1992) Production of poly(3- hydroxybutyrate-co-4hydroxybutyrate) by Pseudomonas acidovorans. Biotechnol Lett 14:445-450

Kumar S, Tamura K, Nei M (2004) MEGA3: integrated software for molecular evolutionary genetics analysis and sequence alignment. Brief Bioinform 5:150-163

Lane DJ (1991) 16S/23S rRNA sequencing. In: Stackebrandt E, Goodfellow M (eds) Nucleic acid techniques in bacterial systematics. Wiley, Chichester, pp 115-175

Lee SY, Choi II (2004) Polyhydroxyalkanoates: biodegradeable polymer. In: Demain AL, Davies JE, Atlas RM, Cohen G, Hershberger CL, Hu WS, Sherman DH, Willson RC, David JH (eds) Manual of indusrial microbiology and biotechnology, 2nd edn. American Society of Microbiology, Washington, pp pp 616-pp 624

Linko S, Vaheri H, Seppala J (1993) Production of poly- $\beta$-hydroxybutyrate on lactic acid by Alcaligenes eutropgus $\mathrm{H} 16$ in a 31 bioreactor. Enzyme Microb Technol 15:401-406

Liu QJ (1997) Structure and dynamics of the subalpine coniferous forest on Changbai mountain, China. Plant Ecol 132:97-105
Lopez NI, Pettinari MJ, Stackebrandt E, Tribelli PM, Potter M, Steinbuchel A, Mendez BS (2009) Pesudomonas extremaustralis sp nov, a poly(3hydroxybutyrate) producer isolated from an Antarctic environment. Curr Microbiol 59:514-519

Magee CM, Rodeheaver G, Edgerton MT, Edlich RF (1975) A more reliable Gram staining technique for diagnosis of surgical infections. Am J Surg 130:341-346

Moyer C, Morita R (2007) Psychrophiles and psychrotrophs. Encyclopedia of Life Science. doi:10.1002/9780470015902.a0000402.pub2

Page WJ (1992) Production of poly- $\beta$-hydroxybutyrate UWD in media containing sugars and complex nitrogen sources. Appl Microbiol Biotechnol 38:117-121

Spiekermann P, Rehm BHA, Kalscheuer R, Baumeister D, Steinbuchel A (1999) Asensitive, viable-colony staining method using Nile red for direct screening of bacteria that accumulate polyhydroxyalkanoic acids and other lipid storage compounds. Arch Microbiol 17:73-80

Steinbuchel A, Valeniin HE (1995) Diversity of bacterial poly hydroxybutyrate acids. FEMS Microbiol Lett 128:219-228

Steinuchel A, Byrom D (1991) Biomaterials: Novel materials from biological sources. Stockton, New York, pp 123-213

Tang L, Luo GY (2008) Study on nitrogen removal characteristics of an aerobic denitrifying bacterium Rhodococcus strain T7. Environ Ecol Three Gorges 1:24-27

Tribelli PM, lustman LRR, Catone MV, Martino CD, Revale S, Mendez BS, Lopez NI (2012) Genome sequence of the polyhydroxybutyrate producer Pseudomonas extremaustralis, a highly stress-resistant Antarctic bacterium. J Bacteriology 194:2381-2382

Verlinden RA, Hill DJ, Kenward MA, Williams CD, Piotrowska-Seget Z, Radecka IK (2011) Production of polyhydroxyalkanoates from waste frying oil by Cupriavidus necator. AMB Express 1:11-19

Yue WJ, Liu C, Zhang XF (2007) Accumulation of poly- $\beta$-hydroxybutyrate acid (PHB) by Rhodopseudomonas palustris. Environ Sci Technol 30:26-28

\section{doi:10.1186/2193-1801-2-335}

Cite this article as: Li et al:: Psychrotrophic Pseudomonas mandelii CBS-1 produces high levels of poly- $\beta$-hydroxybutyrate. SpringerPlus 2013 2:335.

\section{Submit your manuscript to a SpringerOpen ${ }^{\circ}$ journal and benefit from:}

- Convenient online submission

- Rigorous peer review

- Immediate publication on acceptance

- Open access: articles freely available online

- High visibility within the field

- Retaining the copyright to your article

Submit your next manuscript at springeropen.com 